\title{
EARLY MARKERS OF MAJOR ADVERSE EVENTS IN CHILDREN AFTER CARDIAC OPERATIONS
}

Trevor Duke, FRACP

Warwick Butt, FRACP ${ }^{a}$

Mike South, MD, FRACP

Tom R. Karl, MS, MD
Objectives: The purpose of this study was to determine the physiologic variables that predict major adverse events in children in the intensive care unit after cardiac operations. Methods: A cohort observational study was conducted. At the time of admission to the intensive care unit and 4, 8, 12, and 24 hours later the following variables were recorded: mean arterial pressure, heart rate, cardiac index, oxygen delivery, mixed venous oxygen saturation, base deficit, blood lactate, gastric intramucosal pH, carbon dioxide difference (the difference between arterial carbon dioxide tension and gastric intraluminal carbon dioxide tension), and toe-core temperature gradient. Major adverse events were prospectively identified as cardiac arrest, need for emergency chest opening, development of multiple organ failure, and death. Results: Ninety children were included in the study; 12 had major adverse events and there were 4 deaths. Blood lactate level, mean arterial pressure, and duration of cardiopulmonary bypass were the only significant, independent predictors of major adverse events when measured at the time of admission to the intensive care unit: The odds ratio ( $95 \%$ confidence intervals) for major adverse events if a lactate level was greater than $4.5 \mathrm{mmol} / \mathrm{L}$ was 5.1 (1.2 to 21.1 , for admission hypotension 2.3 (0.5 to 9.8 ), and for a cardiopulmonary bypass time greater than 150 minutes 13.7 (3.3 to 57.2). Four hours after admission lactate and carbon dioxide difference, and 8 hours after admission lactate and base deficit, were independently significant predictors. The odds ratios for major adverse events if the blood lactate level was greater than $4 \mathrm{mmol} / \mathrm{L}$ at 4 and 8 hours were 8.3 (1.8 to 38.4) and 9.3 (1.9 to 44.3), respectively. At no time in the first 24 hours were cardiac output, oxygen delivery, mixed venous oxygen saturation, toe-core temperature gradient, or heart rate significant predictors of major adverse events. Conclusions: In the context of our current treatment strategies, the duration of cardiopulmonary bypass and blood lactate level, measured in the early postoperative period, were the best predictors of impending major adverse events. (J Thorac Cardiovasc Surg 1997;114:1042-52)
In the period immediately after cardiac operations, inadequate cardiac output is a common problem and is associated with substantial morbidity in both

From the Royal Children's Hospital, Paediatric Intensive Care Unit, ${ }^{\text {a }}$ Department of General Paediatrics, ${ }^{\mathrm{b}}$ and Victorian Paediatric Cardiac Surgery Unit, ${ }^{c}$ Parkville, Victoria, Australia.

Supported by a Royal Children's Hospital Research Foundation Fellowship to Dr. Duke for the duration of the study.

Received for publication Nov. 11, 1996; revisions requested Jan. 30, 1997; revisions received June 10, 1997; accepted for publication Jùne 12, 1997

Address for reprints: Mike South, MD, FRACP, Department of Paediatrics, Royal Children's Hospital, Flemington Rd., Parkville, 3052, Victoria, Australia.

Copyright $(0) 1997$ by Mosby-Year Book, Inc.

$0022-5223 / 97 \$ 5.00+0 \quad \mathbf{1 2 / 1 / 8 3 9 0 9}$ children and adults. Identifying patients with inadequate cardiac output can be difficult. The early signs may not be well appreciated, and thus opportunities to avoid potential sequelae (multiple organ failure, cardiac arrest, and death) may be delayed or lost. Several ways for assessing the adequacy of cardiac output have been proposed, but these have not been thoroughly evaluated in children after cardiac operations. Although death after cardiac operations in children is uncommon, major adverse events (MAE) may be frequent. The predictors of these events have not been identified.

Cardiac output measurements are used routinely in the treatment of adults after heart operations. The lack of availability of small cannulas for thermodilution cardiac output measurements, difficulties of cannulation in small infants, complications of 
pulmonary artery cannulas, and uncertainty about the meaning of the results obtained have limited the use of these measurements in pediatric intensive care. Unfortunately, noninvasive methods of measuring cardiac output, such as Doppler echocardiography, have been shown in our unit to have poor agreement with the relative gold standards of the Fick and indicator dilution methods (J. Beca, unpublished data).

Gastric tonometry was developed by vascular surgeons to estimate the $\mathrm{pH}$ of the gastrointestinal tract lining $(\mathrm{pHi})$. In adults supported by cardiopulmonary bypass there was found to be a negative correlation between $\mathrm{pHi}$ and hepatic venous lactate levels and a positive correlation between $\mathrm{pHi}$ and hepatic venous oxygen saturation and hepatic venous $\mathrm{pH} .{ }^{1}$ In critically ill adults the incidence of low $\mathrm{pHi}$ has been reported to be as high as $80 \%$ for patients with multiple organ system failure, ${ }^{2} 50 \%$ after cardiac operations, ${ }^{3}$ and $18 \%$ after abdominal aortic operations. ${ }^{4}$ Several investigators have claimed that shock and patients at risk for major complications may be identified earliest by $\mathrm{pHi}$ monitoring. ${ }^{5,6}$ The information derived from tonometry in children after cardiac operations has not been well evaluated. $\mathrm{DCO}_{2}$, the difference between the partial pressures of gastric intraluminal carbon dioxide $\left(\mathrm{PicO}_{2}\right)$ and arterial carbon dioxide $\left(\mathrm{PaCO}_{2}\right)$ is a simpler calculated variable that may overcome some of the assumptions made in the calculation of pHi.

Mixed venous oxygen saturation $\left(\mathrm{SvO}_{2}\right)$, measured with blood sampled from the pulmonary artery, when compared with arterial oxygen saturation, represents the balance between oxygen delivery and consumption. ${ }^{7}$ Anything that leads to reduced oxygen delivery such as decreases in cardiac output, hemoglobin, or arterial oxygen saturation may lead to mixed venous desaturation. Increases in oxygen consumption that are not met by increased oxygen delivery will also lead to reduced $\mathrm{Svo}_{2}$.

Base deficit is a calculated value that estimates the metabolic component of the blood $\mathrm{pH}$. It is the amount of base in millimoles required to titrate $1 \mathrm{~L}$ of whole blood to a $\mathrm{pH}$ of 7.40 with the sample fully saturated with oxygen at $37^{\circ} \mathrm{C}$ and at a $\mathrm{PaCO}_{2}$ of 40 $\mathrm{mm} \mathrm{Hg} .{ }^{9}$ In adults after trauma a large base deficit is one of the most sensitive predictors of transfusion requirements, ${ }^{10}$ the presence of serious intraabdominal injury, ${ }^{11}$ the development of multiple organ system failure, ${ }^{12}$ and mortality. ${ }^{9}$ The role of base deficit in predicting sequelae after cardiac operations has not been evaluated.

Toe temperature has been used as a measure of peripheral perfusion in children after cardiac operations, ${ }^{13-16}$ and a large toe-core temperature gradient has been said to be a predictor of postoperative mortality. ${ }^{13}$ High blood lactate concentrations have been associated with increased mortality and morbidity in children after cardiac operations, ${ }^{17}$ but the predictive value has not been compared with those of other measures. Hypotension may be a late and unreliable sign of low cardiac output, ${ }^{18}$ and restoration of.blood pressure alone may not be a sufficiently precise goal for resuscitation. ${ }^{19}$

The aims of this study were to determine the variable or variables that were the earliest physiologic signs that identified children who had MAE and to compare the information provided by gastric tonometry and cardiac output measures with other physiologic variables. The MAE we were interested in predicting were cardiac arrest, need for emergency chest reopening, sepsis, multiple organ failure, and death. The variables evaluated were mean arterial pressure, heart rate, cardiac index, oxygen delivery, $\mathrm{Svo}_{2}$, base deficit, arterial blood lactate, gastric intramucosal $\mathrm{pH}, \mathrm{DcO}_{2}$, and toe-core temperature gradient.

\section{Patients and methods}

The study was approved by the Institutional Ethics in Human Research Committee, and informed verbal consent was obtained from the parents of all participating children.

A cohort observational study was conducted. Children eligible for inclusion in the study were those undergoing cardiac operations with the use of cardiopulmonary bypass. Because we measured cardiac output by thermodilution we predominantly included those who underwent a complete repair of congenital cardiac anomalies, or cardiac transplantation, and others who would routinely have a pulmonary artery catheter inserted for postoperative monitoring. All children had a tonometer (TRIP Sigmoid catheter, Tonometrics Inc.) inserted into the stomach via the orogastric route after induction of anesthesia. The following monitoring catheters were also inserted either percutaneously, before the start of cardiopulmonary bypass, or transthoracically during the operation: peripheral arterial cannula for monitoring blood pressure and for blood sampling; double-lumen internal jugular venous catheter for monitoring central venous pressure and for the administration of inotropic agents, fluids, and other drugs; a left atrial catheter; a pulmonary arterial catheter (Baxter Edwards 3.5F thermodilution catheter); and a right atrial catheter for measurement of cardiac output.

On admission to the intensive care unit after the operation (time 0 ) and at $4,8,12$, and 24 hours after 
Table I. Cardiac lesions and operations in 90 children

\begin{tabular}{lr}
\hline \multicolumn{1}{c}{ Cardiac anomaly and operation } & No. \\
\hline VSD, repair* & 23 \\
Transposition of great arteries, arterial switch $\dagger$ & 23 \\
Atrioventricular septal defect, repair & 14 \\
Hypoplastic left heart syndrome, Norwood operation & 5 \\
Truncus arteriosus, repair & 5 \\
Total anomalous pulmonary venous return, repair & 3 \\
Cardiomyopathy, transplant & 2 \\
Mitral insufficiency, mitral valve replacement & 2 \\
Pulmonary atresia, VSD, repair & 2 \\
Tetralogy of Fallot, repair & 2 \\
Aortic incompetence, Ross procedure & 1 \\
Aortic aneurysm, repair & 1 \\
Coarctation of aorta, repair & 1 \\
Aortic stenosis, valvotomy & 1 \\
Double-outlet right ventricle, repair & 1 \\
Double-outlet right ventricle, pulmonary artery band & 1 \\
Damus-Kaye-Stansel repair & 1 \\
Ebstein anomaly, Blalock-Taussig shunt & 1 \\
Hypoplastic right ventricle, central shunt & 1
\end{tabular}

VSD, Ventricular septal defect.

*Includes two atrial septal defect and ventricular septal defect repairs, one coarctation ventricular septal defect, and one ventricular septal defect interrupted aortic arch.

$\dagger$ Includes one Senning and switch procedure, two two-stage switch procedures, one Taussig-Bing anomaly correction.

admission the following physiologic variables were recorded: mean arterial pressure, heart rate, cardiac index, oxygen delivery, $\mathrm{Svo}_{2}$, base deficit, blood lactate, $\mathrm{pHi}$, $\mathrm{DCO}_{2}$, and toe-core temperature gradient.

Confirmation of the position of the tonometer in the lumen of the stomach was assessed radiographically. The following method was used to estimate pHi and $\mathrm{DCO}_{2}$. Sterile saline solution, $2.5 \mathrm{ml}$, was infused into the catheter opening port to fill the tonometer balloon. A period of equilibration of either 60 or 90 minutes was allowed. The equilibration period allowed time for $\mathrm{CO}_{2}$ in the stomach lumen to diffuse through the silicone balloon into the saline solution. At the time of measurement, the dead space of $1 \mathrm{ml}$ of saline solution was aspirated and discarded and the remaining saline solution $(1.5 \mathrm{ml})$ aspirated into a plain $2.5 \mathrm{ml}$ syringe for analysis of partial pressure of $\mathrm{CO}_{2}$. The $\mathrm{PicO}_{2}$ was measured with use of an ABL510 or ABL620 (Radiometer, Copenhagen) blood gas analyzer. The $\mathrm{PicO}_{2}$ value was then adjusted for the time of equilibration in the lumen of the stomach, according to the manufacturer's product information literature. ${ }^{20}$ The adjusted $\mathrm{PicO}_{2}$ value and the arterial bicarbonate concentration were then used in a modified form of the HendersonHasselbalch equation to calculate gastric intramucosal $\mathrm{pH}^{20-22}$ The modified Henderson-Hasselbalch equation is as follows:

$$
\mathrm{pHi}=6.1+\log _{10}\left(\mathrm{HCO}_{3} / \mathrm{PiCO}_{2[\text { adjusted] }} \times 0.03\right)
$$

where 6.1 is the negative logarithm of the acid dissociation constant of plasma, 0.03 is the solubility coefficient of the
$\mathrm{HCO}_{3} / \mathrm{CO}_{2}$ system in plasma at $37^{\circ} \mathrm{C}$, and $\mathrm{Pico}_{2 \text { (adjusted) }}$ is the partial pressure of carbon dioxide measured from the tonometer saline solution corrected for equilibration time in the tonometer. ${ }^{20}$ The $\mathrm{Dco}_{2}$ was calculated as the difference between the corrected $\mathrm{Pico}_{2}$ and the $\mathrm{Paco}_{2}$.

Cardiac output was measured with $1 \mathrm{ml}$ injectate volumes of normal saline solution, cooled to $0^{\circ}$ to $5^{\circ} \mathrm{C}$ in crushed ice. The injections were made rapidly into the right atrial cannula during the end-expiratory phase of respiration, with all other bolus intravenous infusions ceased. Four readings were made, 1 minute apart, and the cardiac output taken as the computer-generated average of the last three readings. Large residual shunts, which would have introduced errors into the estimation, were excluded by measurement of oxygen saturation from the right atrial, pulmonary arterial, left atrial, and arterial cannulas.

Oxygen delivery was calculated by the standard formu1a. ${ }^{23} \mathrm{SvO}_{2}$ was measured from pulmonary arterial blood with an ABL Co-Oximeter instrument (Radiometer, Copenhagen). Base deficit was measured in arterial blood with an ABL510 or ABL620 blood gas analyzer (Radiometer, Copenhagen). Lactate was measured from arterial blood with a Kodak Ektachem analyzer. The core temperature was taken as the pulmonary artery blood temperature measured with the pulmonary arterial catheter thermistor.

MAE were defined as the following predetermined postoperative events: death, cardiac arrest necessitating resuscitation with cardiac massage and adrenaline, need for emergency chest reopening, and an increase of three or more organ systems failing at 48 hours (compared with the status at the time of admission). Definitions of organ system failure were developed from the literature on normal age-dependent hematologic, ${ }^{24}$ biochemical, ${ }^{25}$ and physiologic values ${ }^{26}$ and from adult definitions of organ failure ${ }^{27}$ adapted to pediatric practice (see appendix). The aim was to find the best physiologic variable or variables that would identify these children early in the postoperative period. Apart from the variables just mentioned we also tested whether other information thought to be associated with postbypass organ dysfunction, including the duration of cardiopulmonary bypass, aortic crossclamping, and circulatory arrest, would help to identify this group of children.

Statistical analysis. The data were entered into a Microsoft Excel spreadsheet and analyzed with Stata for Windows (Stata Corporation). The variables were examined with univariable logistic-regression analysis to determine those of statistical significance. Multivariable logistic-regression analysis was used to evaluate the best combination of variables having independent statistical significance, and odds ratios, $95 \%$ confidence intervals, and positive and negative predictive values were determined. The positive predictive value of a test is the percentage of persons with an abnormal result in whom the outcome in question develops; the negative predictive value is the percentage of persons who have a negative test result in whom the outcome does not develop. Normally distributed data are presented as mean (plus or minus the standard deviation). For 
Table II. MAE in 12 of 90 children after cardiac operations

\begin{tabular}{|c|c|c|c|}
\hline No. & Cardiac operation & $M A E$ & $\begin{array}{l}\text { Hours after } \\
\text { ICU admission }\end{array}$ \\
\hline \multirow[t]{3}{*}{4} & Arterial switch for Taussig-Bing anomaly & Cardiac arrest & 16 \\
\hline & & Emergency chest opening & 16.5 \\
\hline & & Multiple organ failure & 24 \\
\hline \multirow[t]{2}{*}{7} & AVSD repair & Cardiac arrest & 6 \\
\hline & & Emergency chest opening & 6.5 \\
\hline \multirow[t]{2}{*}{23} & VSD, ASD repair & Cardiac arrest & 14 \\
\hline & & Emergency chest opening & 14.5 \\
\hline \multirow[t]{3}{*}{45} & Aortic arch reconstruction & Cardiac arrest & $2.5,72$ \\
\hline & & Multiple organ failure & 24 \\
\hline & & Death & 72 \\
\hline \multirow[t]{4}{*}{49} & Norwood procedure for hypoplastic left heart syndrome & Cardiac arrest & 0,96 \\
\hline & & ECLS & 0 \\
\hline & & Sepsis & 72 \\
\hline & & Death & 96 \\
\hline \multirow[t]{4}{*}{50} & Damus-Kaye-Stansel repair & Cardiac arrest & 0,100 \\
\hline & & ECLS & 0 \\
\hline & & Sepsis & 48 \\
\hline & & Multiple organ failure & 24 \\
\hline \multirow[t]{2}{*}{72} & Arterial switch & Cardiac arrest & 2 \\
\hline & & Emergency chest opening & 3 \\
\hline 74 & Ross repair & Multiple organ failure & 48 \\
\hline 76 & Tetralogy of Fallot repair & Multiple organ failure & 24 \\
\hline \multirow[t]{4}{*}{77} & Truncus arteriosus repair & Cardiac arrest & $12,13,15$ \\
\hline & & ECLS & 17 \\
\hline & & Multiple organ failure & 48 \\
\hline & & Death & 168 \\
\hline 80 & Arterial switch for TGA & Cardiac arrest & 9 \\
\hline 84 & Arterial switch for TGA & Multiple organ failure & 24 \\
\hline
\end{tabular}

$\overline{I C U}$, Intensive care unit; $A V S D$, atrioventricular septal defect; $V S D$, ventricular septal defect; $A S D$, atrial septal defect; $E C L S$, extracorporeal life support; $T G A$, transposition of the great arteries.

within-subject comparisons of normally distributed data, Student's two-tailed paired $t$ test was done. For nonnormally distributed data, within-subject analysis was done by Wilcoxon signed-rank test, and the data are presented as median (interquartile range). A $p$ value of less than 0.05 was considered statistically significant. Logit transformation of the significant variables was done, and log likelihood plots constructed showing the predicted probability of an MAE for given values of the variable. ${ }^{28}$

\section{Results}

Patient characteristics. Ninety infants and children were studied during an 18 -month period. The median age was 2.65 months ( 0.5 to 5.75 months). The median weight was $4.1 \mathrm{~kg}$ (3.5 to 5.6). The operations performed are outlined in Table $\mathrm{I}$. The median duration of cardiopulmonary bypass was 103 minutes (76 to 150 ) and the median aortic crossclamp time 51 minutes (40 to 71 ). Twenty-one percent of the operations were performed with circulatory arrest.
Changes in cardiac index and markers of tissue perfusion after cardiac operations. Thermodilution cardiac output readings were possible in 70 children. The reasons measurements were not able to be done were unfavorable cardiac anatomy after the operation, ${ }^{9}$ unexpected residual intracardiac shunts, ${ }^{4}$ pulmonary arterial catheter malfunction, ${ }^{5}$ and pulmonary arterial or right atrial catheter malposition. ${ }^{2}$ In the first 4 hours after admission to the intensive care unit, cardiac index values fell from a mean of $4.06 \pm$ 1.25 to $3.63 \pm 1.25 \mathrm{~L} / \mathrm{min}$ per square meter $(p=$ $0.001)$. The reduction in cardiac index was sustained at 8 hours (mean $3.61 \pm 1.23 \mathrm{~L} /$ min per square meter). Although there was an early fall in cardiac index values, oxygen delivery was unchanged from admission ( $450 \pm 153 \mathrm{ml} / \mathrm{min}$ per square meter) to 4 hours $(429 \pm 156 \mathrm{ml} / \mathrm{min}$ per square meter) $(p=$ 0.21 ). Maintenance of oxygen delivery occurred because of an increase in the oxygen-carrying capacity of the blood: the hemoglobin value increased 


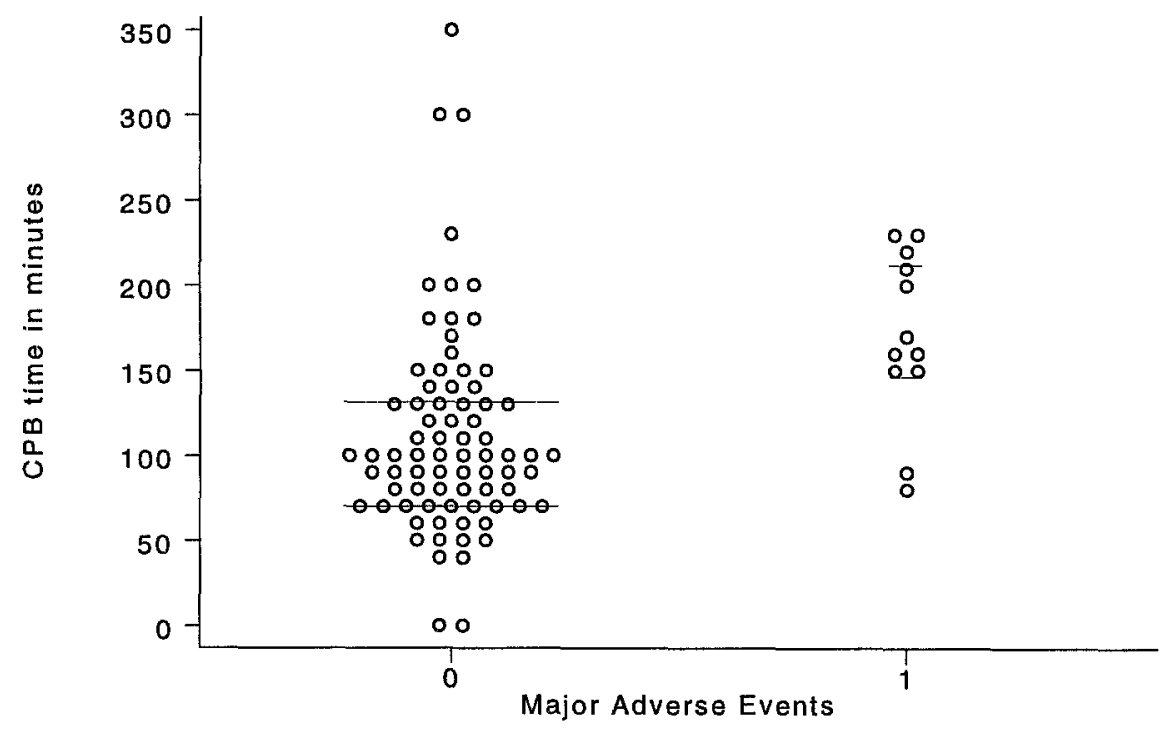

Fig. 1. Cardiopulmonary bypass $(C P B)$ time according to the presence of MAE. Horizontal bars are interquartile ranges. MAE are designated as 0 , no MAE; 1 , MAE.

Table III. Predictive value for MEA of independently statistically significant variables, measured at intensive care unit admission and 4 and 8 hours

\begin{tabular}{|c|c|c|c|c|c|c|}
\hline Variable and value & Odds ratio & $95 \% \mathrm{Cl}$ & $P P V$ & $N P V$ & Sensitivity & Specificity \\
\hline \multicolumn{7}{|l|}{ Admission } \\
\hline $\mathrm{CPB}>150 \mathrm{~min}$. & 13.7 & $3.3-57.2$ & 39 & 96 & 75 & 82 \\
\hline Lactate $>4.5 \mathrm{mmol} / \mathrm{L}$ & 5.1 & $1.2-21.1$ & 36 & 90 & 33 & 91 \\
\hline Hypotension* & 2.3 & $0.5-9.8$ & 23 & 88 & 25 & 87 \\
\hline \multicolumn{7}{|l|}{$4 \mathrm{Hr}$} \\
\hline Lactate $>4 \mathrm{mmol} / \mathrm{L}$ & 8.3 & $1.8-38.4$ & 44 & 91 & 36 & 94 \\
\hline $\mathrm{DCO}_{2}>20 \mathrm{~mm} \mathrm{Hg}$ & 6.9 & $1.3-36.7$ & 42 & 90 & 27 & 95 \\
\hline \multicolumn{7}{|l|}{$8 \mathrm{Hr}$} \\
\hline Lactate $>4 \mathrm{mmol} / \mathrm{L}$ & 9.3 & $1.9-44.3$ & 50 & 90 & 33 & 95 \\
\hline $\mathrm{BD}>-5 \mathrm{mmol} / \mathrm{L}$ & 6.2 & $1.2-32.1$ & 43 & 89 & 33 & 95 \\
\hline
\end{tabular}

$C I$, Confidence intervals; $P P V$, positive predictive value; $N P V$, negative predictive value.

${ }^{*}$ Hypotension is defined as mean arterial pressure less than 2.5 th percentile for age.

from $11.95(10.5$ to 12.9$) \mathrm{gm} / \mathrm{dl}$ to 12.25 (11.3 to $13.5) \mathrm{gm} / \mathrm{dl}$ during the first 4 hours of intensive care unit stay $(p<0.01)$. There was a further increase in hemoglobin levels at 8 hours to 12.9 (11.8 to 14 ) $\mathrm{gm} / \mathrm{dl}(p=0.01)$.

Overall there were reductions in blood lactate values in the first 8 hours after the operations from $2.4(1.9$ to 3.7$) \mathrm{mmol} / \mathrm{L}$ to $1.8(1.4$ to 2.3$) \mathrm{mmol} / \mathrm{L}$ $(p=0.001)$. There were no statistically significant changes in base deficit $(p=0.44)$, pHi $(p=0.45)$, $\mathrm{Dco}_{2}(p=0.20)$, or $\mathrm{Svo}_{2}(p=0.45)$ from admission to 8 hours later.

Adverse events in the postoperative period. MAE occurred in 12 children $(13.3 \%$ ) (Table II). There were four deaths in the series $(4.4 \%)$. Nine children $(10 \%)$ had a cardiac arrest necessitating cardiac massage or emergency chest opening in the intensive care unit. Six children $(6.7 \%)$ had severe multiple organ failure with an increase of more than three organ systems failing in the 48 hours after the operation. Three of these were children who also had a cardiac arrest. In addition to these 12 children, $8(8.9 \%)$ had two organ systems failing and 21 $(23.3 \%)$ had one organ system failing by 48 hours after admission. The 12 children who had an MAE consumed greater intensive care resources, with a longer duration of stay in the intensive care unit. Length of stay was 67 hours (47 to 99) for children without MAE and 120 hours for those with MAE (94 to 185) $(p<0.001)$. The children who had an MAE also had a longer duration of mechanical ventilation: 127 hours ( 68 to 150 ) compared with 41 


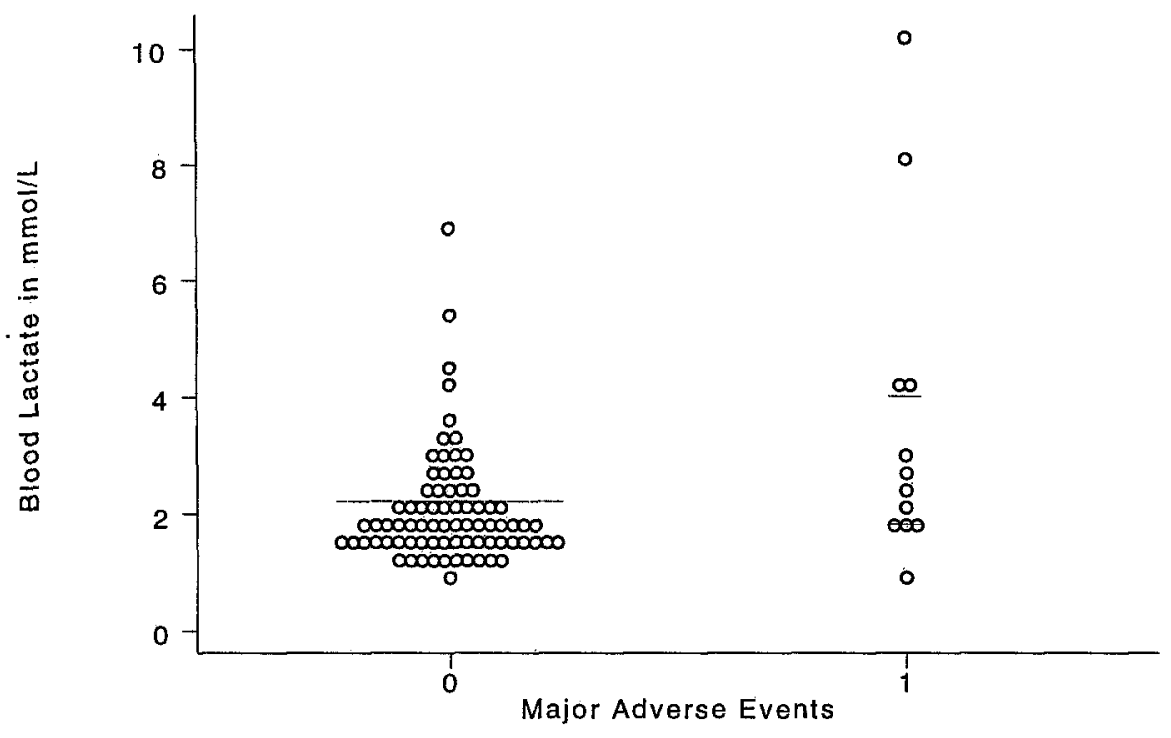

Fig. 2. Blood lactate levels measured 4 hours after intensive care unit admission. Horizontal bars are interquartile range. MAE are designated as 0 , no MAE; 1, MAE.

(24 to 66$)(p<0.001)$. Three of these 12 children received extracorporeal life support, and all three died.

The timing of MAE has relevance to whether there is potentially preventable morbidity or mortality by improved monitoring techniques. The first MAE occurred within 1 hour after the operation in two patients, between 1 and 4 hours in another two patients, and between 4 and 24 hours in seven patients, and in one patient the MAE was not evident until 48 hours after the operation.

Prediction of MAE with operating room data. The durations of both cardiopulmonary bypass and aortic crossclamping were significant positive predictors of MAE (Fig. 1, Table III). The odds ratio (95\% confidence intervals) of a cardiopulmonary bypass time greater than 150 minutes was 13.7 (3.3 to 57.2). The gastric $\mathrm{pHi}$ and $\mathrm{DcO}_{2}$ measured 1 hour after institution of cardiopulmonary bypass did not predict MAE. The median $\mathrm{pHi}$, measured in 81 children, was 7.34 (7.28 to 7.40 ), and the median $\mathrm{Dco}_{2}$ was $8.4 \mathrm{~mm} \mathrm{Hg}$ (2.5 to 14.7 ). Among children with an MAE the median pHi was 7.35 (7.32 to 7.41), whereas in those free of MAE the pHi was 7.34 ( 7.27 to 7.40$)$. The corresponding values of $\mathrm{Dco}_{2}$ were 6.5 (2.6 to 11.9) for patients with and 9.03 (2.5 to 14.8) for those without MAE ( $p=0.43$ ).

Prediction of MAE with admission values of physiologic variables. The monitoring variables measured at the time of admission to the intensive care unit and at 4 and 8 hours are summarized in Table IV. The only physiologic measurements that predicted MAE when measured at the time of admission were the blood lactate values (Tables III and IV) and admission values of age-adjusted mean arterial pressure. Oxygen delivery on admission approached significance on univariate analysis, but was not independently predictive $(p=0.42)$ in a model with lactate and mean arterial pressure. The odds ratios, positive predictive value, negative predictive value, sensitivity, and specificity of the significant variables are summarized in Table III.

Death was predicted at intensive care unit admission only by blood lactate value $(p=0.03)$ and not by any of the other physiologic measures. The odds ratio for death if the admission blood lactate level was greater than $4.5 \mathrm{mmol} / \mathrm{L}$ was 29.3 (2.7 to 315 ).

Prediction of MAE with physiologic variables measured at 4 hours. Four hours after intensive care unit admission, lactate remained a clinically significant predictor of MAE $(p=0.009)$ (Figs. 2 and 3, Tables III and IV). At this time, also significant in a model with lactate were $\operatorname{Dco}_{2}(p=0.006)$ and gastric $\mathrm{pHi}(\mathrm{p}=0.01) . \mathrm{Dco}_{2}$ and $\mathrm{pHi}$ did not have independent significance, which was not surprising because they are mathematically coupled variables.

Prediction of MAE with physiologic variables measured at 8 hours. At 8 hours, values of blood lactate $(p<0.0001)$, base deficit $(p=0.019), \mathrm{Dco}_{2}$ 
Table IV. Physiologic variables measured at admission and 4 and 8 hours according to the development of major complications

\begin{tabular}{|c|c|c|c|c|c|c|c|c|}
\hline \multirow[b]{2}{*}{$\begin{array}{c}\text { Physiologic } \\
\text { variable }\end{array}$} & \multicolumn{4}{|c|}{ Admission to $I C U$} & \multicolumn{4}{|c|}{4 Hr after admission } \\
\hline & $M A E$ & No $M A E$ & $\begin{array}{l}\text { Odds ratio } \\
(95 \% C I)\end{array}$ & $\begin{array}{l}\text { Univariate } \\
\text { logistic } \\
\text { regression } \\
p \text { value }\end{array}$ & $M A E$ & No $M A E$ & $\begin{array}{l}\text { Odds ratio } \\
(95 \% \mathrm{Cl})\end{array}$ & $\begin{array}{c}\text { Univariate } \\
\text { logistic } \\
\text { regression } \\
p \text { value }\end{array}$ \\
\hline $\begin{array}{c}\text { Mean arterial } \\
\text { pressure* }^{*}\end{array}$ & $\begin{array}{l}109.4 \\
(90.6-121.1)\end{array}$ & $\begin{array}{c}124.7 \\
(107.1-137.5)\end{array}$ & $\begin{array}{c}0.96 \\
(0.93-0.99)\end{array}$ & 0.03 & $\begin{array}{l}106 \\
(94-124)\end{array}$ & $\begin{array}{l}113 \\
(107-128)\end{array}$ & $\begin{array}{c}0.98 \\
(0.94-1.01)\end{array}$ & 0.22 \\
\hline Heart rate $\dagger$ & $\begin{array}{c}98.3 \\
(84.9-106.4)\end{array}$ & $\begin{array}{l}104.0 \\
(91.9-114.7)\end{array}$ & $\begin{array}{c}0.97 \\
(0.93-1.01)\end{array}$ & 0.12 & $\begin{array}{l}107 \\
(94-122)\end{array}$ & $\begin{array}{l}101 \\
(87-115)\end{array}$ & $\begin{array}{c}1.01 \\
(0.98-1.05)\end{array}$ & 0.08 \\
\hline $\begin{array}{l}\text { Cardiac index } \\
\left(\mathrm{L} / \mathrm{min} / \mathrm{m}^{2}\right) \\
(N=70)\end{array}$ & $\begin{array}{c}3.45 \\
(2.45-4.22)\end{array}$ & $\begin{array}{c}4.22 \\
(3.35-4.67)\end{array}$ & $\begin{array}{c}0.70 \\
(0.38-1.29)\end{array}$ & 0.25 & $\begin{array}{c}3.10 \\
(2.8-4.1) \\
(N=8)\end{array}$ & $\begin{array}{c}3.36 \\
(2.70-4.50) \\
(N=62)\end{array}$ & $\begin{array}{c}0.77 \\
(0.41-1.47)\end{array}$ & 0.33 \\
\hline $\begin{array}{c}\mathrm{DO}_{2}(\mathrm{ml} / \\
\mathrm{min} / \mathrm{m}^{2} \\
(N=70)\end{array}$ & $\begin{array}{c}619.4 \\
(492.1-716.0)\end{array}$ & $\begin{array}{c}470.4 \\
(306.6-670.5)\end{array}$ & $\begin{array}{c}0.96 \\
(0.93-1.01)\end{array}$ & 0.09 & $\begin{array}{c}559.1 \\
(412.6-677.5)\end{array}$ & $\begin{array}{c}530.3 \\
(413.1-674.8)\end{array}$ & $\begin{array}{c}0.99 \\
(0.96-1.03)\end{array}$ & 0.71 \\
\hline $\begin{array}{l}\mathrm{SvO}_{2}(\%) \\
\quad(N=70)\end{array}$ & $\begin{array}{c}48.9 \\
(46.7-64.4)\end{array}$ & $\begin{array}{c}61.7 \\
(53.6-67.4)\end{array}$ & $\begin{array}{c}0.95 \\
(0.88-1.01)\end{array}$ & 0.12 & $\begin{array}{c}55.1 \\
(47.5-59.7) \\
(N=8)\end{array}$ & $\begin{array}{c}62.1 \\
(54.2-67.7) \\
(N=62)\end{array}$ & $\begin{array}{c}0.93 \\
(0.85-1.01)\end{array}$ & 0.24 \\
\hline $\begin{array}{l}\text { Base deficit } \\
(\mathrm{mmol} / \mathrm{L})\end{array}$ & $\begin{array}{c}-2.4 \\
(-3.2-0.5)\end{array}$ & $\begin{array}{c}-0.4 \\
(-2.2-1.5)\end{array}$ & $\begin{array}{c}0.84 \\
(0.67-1.06)\end{array}$ & 0.14 & $\begin{array}{c}-2.2 \\
(-4.1-0.1)\end{array}$ & $\begin{array}{c}-0.15 \\
(-2.4-1.9)\end{array}$ & $\begin{array}{c}0.82 \\
(0.67-1.00)\end{array}$ & 0.05 \\
\hline $\begin{array}{l}\text { Lactate } \\
\quad(\mathrm{mmol} / \mathrm{L})\end{array}$ & $\begin{array}{c}3.0 \\
(2.1-4.9)\end{array}$ & $\begin{array}{c}2.2 \\
(2.0-3.5)\end{array}$ & $\begin{array}{c}1.36 \\
(1.03-1.80)\end{array}$ & 0.03 & $\begin{array}{c}2.5 \\
(1.9-4.1)\end{array}$ & $\begin{array}{c}1.8 \\
(1.5-2.3)\end{array}$ & $\begin{array}{c}1.71 \\
(1.14-2.60)\end{array}$ & $<0.01$ \\
\hline $\begin{array}{l}\text { Gastric } \mathrm{pHi} \\
\text { (pH units) }\end{array}$ & $\begin{array}{c}7.26 \\
(7.20-7.33)\end{array}$ & $\begin{array}{c}7.31 \\
(7.25-7.36)\end{array}$ & $\begin{array}{c}0.64 \\
(0.33-1.27) \neq\end{array}$ & 0.20 & $\begin{array}{c}7.22 \\
(7.16-7.25)\end{array}$ & $\begin{array}{c}7.30 \\
(7.24-7.34)\end{array}$ & $\begin{array}{c}0.25 \\
(0.09-0.64) \ddagger\end{array}$ & 0.01 \\
\hline $\begin{array}{l}\mathrm{DCO}_{2} \\
\quad(\mathrm{~mm} \mathrm{Hg})\end{array}$ & $\begin{array}{c}15.4 \\
(12.1-18)\end{array}$ & $\begin{array}{c}12.9 \\
(8.4-18.2)\end{array}$ & $\begin{array}{c}0.96 \\
(0.93-1.01)\end{array}$ & 0.30 & $\begin{array}{c}18.2 \\
(16.3-20.9)\end{array}$ & $\begin{array}{c}12.7 \\
(9.4-15.9)\end{array}$ & $\begin{array}{c}0.99 \\
(0.96-1.03)\end{array}$ & 0.01 \\
\hline $\begin{array}{l}\text { Toe-core temp. } \\
\text { gradient }\left({ }^{\circ} \mathrm{C}\right)\end{array}$ & $\begin{array}{c}3.2 \\
(1.7-4.8)\end{array}$ & $\begin{array}{c}3.2 \\
(1.9-5.7)\end{array}$ & $\begin{array}{c}0.98 \\
(0.77-1.24)\end{array}$ & 0.84 & $\begin{array}{c}3.1 \\
(2.1-5.5)\end{array}$ & $\begin{array}{c}3.0 \\
(1.7-4.3)\end{array}$ & $\begin{array}{c}1.13 \\
(0.90-1.42)\end{array}$ & 0.31 \\
\hline
\end{tabular}

Values presented as median (interquartile range) and $p$ value, derived by univariate logistic-regression. Odds ratios (OR) presented as the change in odds based on a 1 -unit change in value. $I C U$, intensive care unit; $C I$, confidence interval; $\mathrm{DO}_{2}$, oxygen delivery.

* Meari arterial pressure presented as a percentage of the 2.5 th percentile for age.

$\uparrow$ Heart rate presented as percentage of 97.5 th percentile for age.

fOdds ratio for $\mathrm{pHi}$ presented as the change in odds based on a 0.1 -unit change in $\mathrm{pHi}$

$(p=0.027)$, and gastric pHi $(p=0.005)$ were predictors of MAE by univariate logistic-regression analysis (Tables III and IV).

In multivariable models of all the significant variables noted, both lactate $(p=0.008)$ and $\operatorname{Dco}_{2}(p=$ $0.013)$, or lactate $(p=0.003)$ and base deficit $(p=$ 0.021 ), were significant. To determine whether measures made by gastric tonometry when included in a simpler model improved the predictive power, we combined variables with blood lactate, the most consistently significant predictor variable. $\mathrm{DcO}_{2}$ and base deficit were not independent of each other, inasmuch as both were statistically significant in a model with lactate but not in a model containing lactate, base deficit, and $\mathrm{Dco}_{2}$.

Early prediction of less severe adverse events. Because MAE in this series were relatively uncommon, we wondered whether the early predictors of these events were also reliable predictors of less severe but more common adverse events after cardiac operations. The complication that occurred most commonly was the persistence of renal impairment (as defined in the appendix) more than 48 hours after admission to the intensive care unit. This occurred in 26 children (29\%). Children who had persistent renal impairment at 48 hours had an increased length of stay in the intensive care unit $(152 \pm 178$ hours) compared with those in whom renal failure did not develop ( $80 \pm 60$ hours) $(p=$ 0.002 ). The only predictor of persistent renal impairment at 48 hours at the time of admission to the intensive care unit was the admission blood lactate level $(p=0.018)$. The odds ratio for renal impairment if the admission lactate level was greater than $4 \mathrm{mmol} / \mathrm{L}$ was 3.2 (1.1 to 9.5). Renal impairment was not predicted by admission mean arterial pressure $(p=0.35)$, cardiac index $(p=0.85)$, oxygen delivery $(p=0.65)$, base deficit $(p=0.89), \mathrm{pHi}(p=0.63)$, 
8 Hr after admission

\begin{tabular}{|c|c|c|c|}
\hline$M A E$ & No $M A E$ & $\begin{array}{c}\text { Odds ratio } \\
(95 \% \text { CI })\end{array}$ & $\begin{array}{c}\text { Univariate } \\
\text { logistic } \\
\text { regression } \\
p \text { value }\end{array}$ \\
\hline $\begin{array}{l}108 \\
(93-124)\end{array}$ & $\begin{array}{l}116 \\
(106-133)\end{array}$ & $\begin{array}{c}0.98 \\
(0.93-1.03)\end{array}$ & 0.09 \\
\hline $\begin{array}{l}103 \\
(91.9-115.8)\end{array}$ & $\begin{array}{c}93.7 \\
(84.4-114.7)\end{array}$ & $\begin{array}{c}1.02 \\
(0.00-106)\end{array}$ & 0.23 \\
\hline $\begin{array}{c}3.05 \\
(2.66-3.71) \\
(N=8)\end{array}$ & $\begin{array}{c}3.38 \\
(2.78-4.56) \\
(\mathrm{N}=62)\end{array}$ & $\begin{array}{c}0.61 \\
(0.27-1.36)\end{array}$ & 0.27 \\
\hline $\begin{array}{c}558.1 \\
(412.6-677.5)\end{array}$ & $\begin{array}{c}518.2 \\
(413.1-674.8)\end{array}$ & $\begin{array}{c}0.98 \\
(0.93-1.03)\end{array}$ & 0.42 \\
\hline $\begin{array}{l}56.6 \\
(49-59.8)\end{array}$ & $\begin{array}{c}60.2 \\
(53.6-66.4)\end{array}$ & $\begin{array}{c}0.92 \\
(0.84-1.01)\end{array}$ & 0.06 \\
\hline $\begin{array}{l}(N=8) \\
-0.29\end{array}$ & $\begin{array}{c}(N=62) \\
-0.65\end{array}$ & 0.78 & 0.02 \\
\hline$(-5.2-0.15)$ & $(-2.4-1.9)$ & $(0.63-0.97)$ & \\
\hline $\begin{array}{c}3.1 \\
(1.8-4.9)\end{array}$ & $\begin{array}{c}1.7 \\
(1.4-2.1)\end{array}$ & $\begin{array}{c}3.05 \\
(1.44-6.44)\end{array}$ & $<0.01$ \\
\hline $\begin{array}{c}7.25 \\
(7.14-7.29)\end{array}$ & $\begin{array}{c}7.30 \\
(7.23-7.35)\end{array}$ & $\begin{array}{c}0.31 \\
(0.13-0.75) \ddagger\end{array}$ & $<0.01$ \\
\hline $\begin{array}{c}15.2 \\
(11.8-23.1)\end{array}$ & $\begin{array}{c}11.4 \\
(9.5-15.3)\end{array}$ & $\begin{array}{c}0.98 \\
(0.93-1.03)\end{array}$ & 0.03 \\
\hline $\begin{array}{c}3.0 \\
(2.0-4.6)\end{array}$ & $\begin{array}{c}2.5 \\
(1.5-4.2)\end{array}$ & $\begin{array}{c}1.08 \\
(0.87-1.34)\end{array}$ & 0.48 \\
\hline
\end{tabular}

$\mathrm{Dco}_{2}(p=0.57), \mathrm{Svo}_{2}(p=0.71)$, or toe-core temperature gradient $(p=0.31)$.

\section{Discussion}

This study aimed to determine the best and earliest predictors of MAE in children after cardiac operations. It has been suggested that measures made by gastric tonometry would identify postoperative complications earlier than other measures., 29 MAE after pediatric cardiac operations are relatively uncommon. ${ }^{30}$ The probability in this series was $13 \%$. Complications were only included if they were likely to be associated with clinically important morbidity or a high risk of mortality. The MAE identified were associated with prolonged intensive care and hospital stay. It is possible that identification of these children early, and the institution of appropriate therapy, would reduce this morbidity. We found that measures made by gastric tonometry did identify children at risk for MAE after cardiac operations, but that children at risk could be identified earlier by other simpler measures. The best and earliest prediction of impending MAE was by the consideration of the duration of cardiopulmonary bypass, the admission blood lactate level, and the mean arterial pressure. A high blood lactate level was the most consistently predictive variable throughout the early postoperative period of both MAE and more common minor complications, which also add to intensive care unit morbidity and cost. The addition of $\mathrm{Dco}_{2}$ values provided only a marginal increase in the predictive power of more conventionally used tests and only when measured 4 hours after intensive care unit admission. At 8 hours, lactate plus base deficit was a better predictive combination than one that used $\mathrm{DcO}_{2}$. A confounding factor in the interpretation of the predictive power of base deficit is the administration of bicarbonate or other base. None of the subjects in this study received bicarbonate or other base in the first 8 hours after admission to the intensive care unit, but we were unfortunately not able to establish how much was given in the operating room. We do know that some patients had bicarbonate correction of metabolic acidosis during the operation, and this may partly account for the lack of predictive power of the base deficit at the time of admission and 4 hours later.

Thermodilution measures of cardiac index and the derived value of oxygen delivery did not discriminate children who had an MAE from those who had an uncomplicated postoperative course. In our patients left atrial and pulmonary arterial catheters are inserted before chest closure in children in whom cardiac function is likely to be impaired or in whom pulmonary hypertension may be a problem after operation. The only additional advantage of using a thermodilution pulmonary arterial catheter, therefore, is for the measurement of cardiac output and derived hemodynamic and oxygen transport variables. Our evidence suggests that more clinically useful information can be derived from the measurement of markers of the adequacy of tissue oxygenation, such as lactate, than from the absolute value of cardiac output or oxygen delivery.

Hyperlactatemia early after cardiopulmonary bypass may represent intraoperative or early postoperative tissue oxygen debt, impaired lactate clearance, or both. Lactate is cleared by liver, kidneys, heart, and resting skeletal muscle. It may be that a high lactate level is sometimes a surrogate marker of organ dysfunction. We unfortunately did not have any data on preoperative lactate levels to determine whether the presence of hyperlactatemia before the 


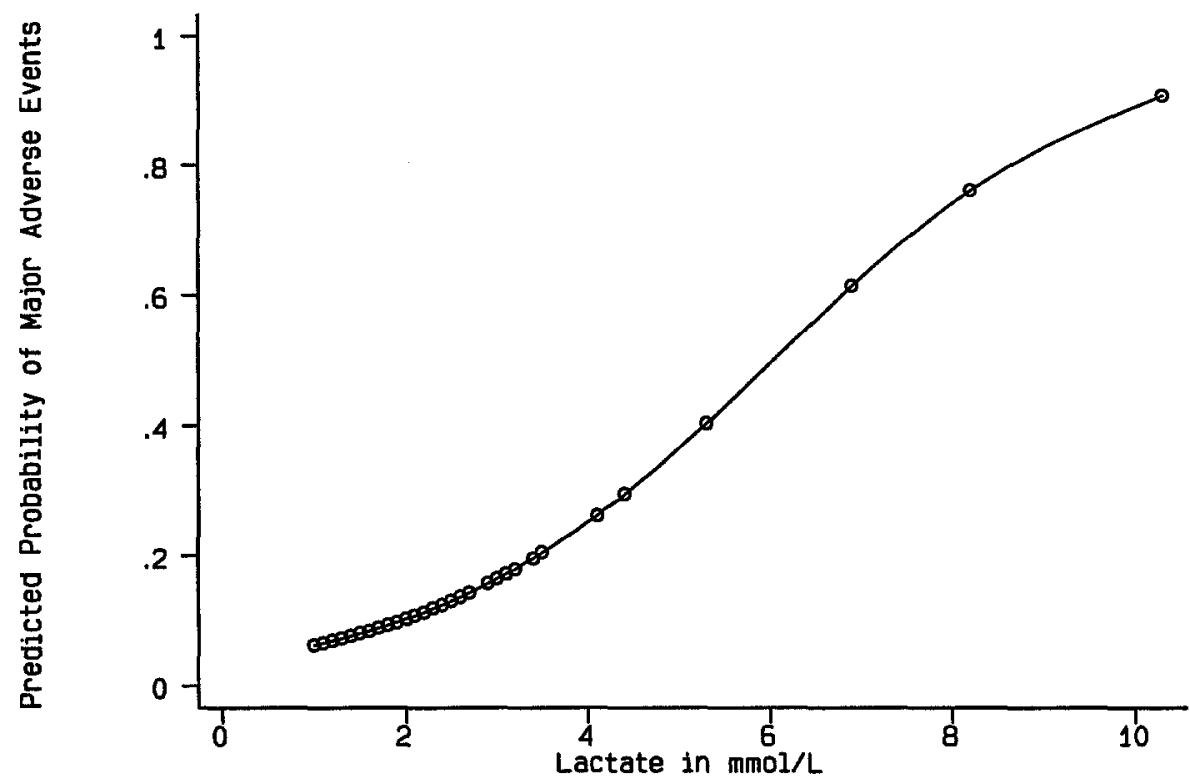

Fig. 3. Log-likelihood plot of the probability of major complications according to lactate level measured 4 hours after admission.

operation predicted postoperative MAE. In our study the finding of a normal lactate level did not preclude the possibility of an MAE. A lactate level greater than $3 \mathrm{mmol} / \mathrm{L}$ at the time of admission to the intensive care unit only identified $50 \%$ of those who subsequently had a major complication, so this had a relatively low sensitivity. Children who had a lactate level greater than $4.5 \mathrm{mmol} / \mathrm{L}$ at the time of admission or greater than $5 \mathrm{mmol} / \mathrm{L}$ at 4 hours had a $36 \%$ and $44 \%$ chance, respectively, of an MAE (Table III). In children with a high lactate level on admission, and in those in whom a high lactate level persists after the operation, efforts should be made to search for remediable problems and to optimize tissue oxygenation. Before this study lactate was not routinely measured in our intensive care unit after cardiac operations. Although the results of lactate measures during the study were available to treating clinicians we did not have a specific management strategy to deal with hyperlactatemia. Further work is required to determine whether alteration in management based on an elevated lactate level would avoid any MAE.

The finding that a long duration of cardiopulmonary bypass was strongly related to an increased risk of MAE (Fig. 1, Table III) may reflect the complexity of the cardiac lesion, intraoperative problems related to and independent of the cardiac lesion, and the effects of the host response to cardiopulmo- nary bypass. Any of these factors may be important in the development of MAE.

There may be a selection bias in our results. The subjects were chosen from a larger population of some 400 patients. We aimed to study children who were at high risk for MAE. We predominantly chose children who were undergoing complete repair, rather than palliative procedures, for two reasons. First, we wanted to minimize the number of children in whom a residual lesion may have contributed to the MAE. Second, we wanted to assess and compare the value of thermodilution measures of cardiac output, a method that is inaccurate in the presence of intracardiac shunts. Despite these considerations, the variables found to have the greatest predictive power (lactate, mean arterial pressure, and cardiopulmonary bypass time) are easily measured, and likely to be valid, in children with either repaired or palliated heart lesions.

In conclusion, although $\mathrm{pHi}$ and $\mathrm{DcO}_{2}$ values predicted MAE, they were later warning signs than values of blood lactate, mean arterial pressure, and the duration of cardiopulmonary bypass. The expense of gastric tonometry is considerably greater than that of the measurement of blood lactate and arterial blood gases. There is not enough evidence to recommend the routine use of gastric tonometry or of thermodilution cardiac output measures in children after cardiac operations for the prediction 
of MAE. This was a preliminary study of only 90 patients, in which the number of children with MAE was relatively small, but it suggests that lactate should be measured in children after cardiac operations as a guide to prognosis and as an early warning sign of impending complications. Children who have a long cardiopulmonary bypass time, high blood lactate level, or hypotension on admission to the intensive care unit are at increased risk of MAE, and their postoperative treatment should be planned with this in mind. Further research is needed into the management of hyperlactatemia in children after cardiac operations.

\section{REFERENCES}

1. Landlow L, Phillips DA, Heard SO, Prevost D, Vandersalm TJ, Fink MP. Gastric tonometry and venous oximetry in cardiac surgery patients. Crit Care Med 1991;19:1226-33.

2. Fiddian-Green RG. Hypotension, splanchnic hypoxia and arterial acidosis in ICU patients. Circ Shock 1987;21:326-30.

3. Fiddian-Green RG, Baker S. Predictive value of the stomach wall $\mathrm{pH}$ for complications after cardiac operations: comparison with other monitoring. Crit Care Med 1987;15:153-6.

4. Fiddian-Green RG, Amelin PM, Herrmann JB, Arous E, Cutler BS, Schiedler M. Prediction of the development of sigmoid ischemia on the day of aortic operations. Arch Surg 1986; 121:654-60.

5. Haglund U. Intramucosal pH. Intensive Care Med 1994;20: 90-1.

6. Fiddian-Green RG, Haglund U, Gutierrez G, Shoemaker WC. Goals for the resuscitation of shock. Crit Care Med 1993;21:S25-31.

7. Astiz ME, Rackow EC. Assessing perfusion failure during circulatory shock. Crit Care Clin 1993;9:299-312.

8. Silance PG, Simon C, Vincent J-L. The relation between cardiac index and oxygen extraction in acutely ill patients. Chest 1994;105:1190-7.

9. Rutherford EJ, Morris JA Jr, Reed GW, Hall KS. Base deficit stratifies mortality and determines therapy. J Trauma 1992;33:417-23.

10. Bannon MP, O'Neill CM, Martin M, Ilstrup DM, Fish NM, Barrett J. Central venous oxygen saturation, arterial base deficit, and lactate concentrations in trauma patients. Am Surg 1995;61:738-45.

11. Davis JW, Mackersie RC, Holbrook TL, Hoyte DB. Base deficit as an indicator of significant abdominal injury. Ann Emerg Med 1991;20:842-4.

12. Sauaia A, Moore FA, Moore EE, Haenel JB, Read RA, Lezotte DC. Early predictors of postinjury multiple organ failure. Arch Surg 1995;129:39-45.

13. Knight RW, Opie JC. The big toe in the recovery room: peripheral warm-up patterns in children after open-heart surgery. Can J Surg 1981;24:239-42.

14. Fagan MJ. Relationship between nurses' assessments of perfusion and toe temperature in pediatric patients with cardiovascular disease. Heart Lung 1988;17:157-65.

15. Alexi-Meskhishvilli V, Popov SA, Nikoljuk AP. Evaluation of hemodynamics in infants and small babies after open heart surgery. Thorac Cardiovasc Surg 1984;32:4-9.

16. Shore DF, Capuani A, Lincoln C. Atypical tamponade after cardiac operation in infants and children. $\mathbf{J}$ Thorac Cardiovasc Surg 1982;83:449-52.

17. Siegel LB, Hauser GJ, Hertzog JH, Hopkins RA, Hannan RL, Dalton HJ. Initial postoperative serum lactate predicts outcome in children after open heart surgery [Abstract]. Crit Care Med 1995;23:A205.

18. Wo CCJ, Shoemaker WC, Appel PL, Bishop MH, Kram HB, Hardin E. Unreliability of blood pressure and heart rate to evaluate cardiac output in emergency resuscitation and critical illness. Crit Care Med 1993;21:218-23.

19. Vincent J-L. End-points of resuscitation: arterial blood pressure, oxygen delivery, blood lactate, or . . .? Intensive Care Med 1996;22:3-5.

20. Tonometrics Inc., Tewksbury [MA]. Product information for TRIP Sigmoid Catheter. 1991.

21. Grum CM, Fiddian-Green RG, Pittenger GL, Grant BJB, Rothman ED, Dantzker DR. Adequacy of tissue oxygenation in intact dog intestine. J Appl Physiol 1984;56:1065-9.

22. Fiddian-Green RG, McGough E, Pittenger G, Rothman E. Predictive value of intramural $\mathrm{pH}$ and other risk factors for massive bleeding from stress ulceration. Gastroenterology 1983;85:613-20.

23. Nunn JF. Oxygen. In: Nunn JF, ed. Nunn's applied respiratory physiology. 4th ed. Oxford: Butterworth-Heinemann, 1993:247-305.

24. Andrew M, Paes B, Johnston M. Development of the hemostatic system in the neonate and young infant. Am $\mathrm{J}$ Pediatr Hematol Oncol 1990;12:95-104.

25. Department of Clinical Biochemistry, RCH. Reference ranges in clinical biochemistry. 1st ed. Melbourne: Educational Resources Centre, RCH, 1993:2-23.

26. Shann F. Drug doses. 9th ed. Melbourne: Collective Pty Ltd., 1996:65.

27. Knaus WA, Draper EA, Wagner DP, Zimmerman JE. Prognosis in acute organ-system failure. Ann Surg 1985;202:68593.

28. Hamilton LC. Logistic regression. In: Statistics with Stata 3. 1st ed. Belmont, California: Duxbury, 1993:139-56.

29. Kiefer P, Eichelbronner O, Hannekum A, Georgieff M, Radermacher P. Persistent gastric mucosal acidosis in a child after cardiac surgery. Clin Intensive Care 1995;6:242-4.

30. Seghaye MC, Engelhardt W, Grabitz RG, et al. Multiple system organ failure after open heart surgery in infants and children. Thorac Cardiovasc Surg 1993;41:49-53. 
Appendix Table I. Definitions of organ failure

\begin{tabular}{|c|c|}
\hline Cardiac & $\begin{array}{l}\text { Presence of one or more of the following: } \\
\text { Mean arterial pressure } \\
<30 \mathrm{~mm} \mathrm{Hg} \text { (neonate to } 3 \text { months old) } \\
<35 \mathrm{~mm} \mathrm{Hg} \text { (age } 3 \text { months to } 1 \text { year) } \\
<40 \mathrm{~mm} \mathrm{Hg} \text { (age } 1 \text { year to } 6 \text { years) } \\
<50 \mathrm{~mm} \mathrm{Hg} \text { (>6 years) } \\
\text { Arterial blood pH }<7.25 \text { with } \mathrm{PaCO}_{2}<45 \\
\mathrm{~mm} \mathrm{Hg} \\
\text { Requirement for inotropes more than } 10 \\
\mu \mathrm{g} / \mathrm{kg} \text { per minute dopamine }\end{array}$ \\
\hline Respiratory & $\begin{array}{l}\text { Presence of one or more of the following: } \\
\text { Alveolar-arterial } \mathrm{O}_{2} \text { gradient }>350 \mathrm{~mm} \\
\mathrm{Hg} \\
\text { Ventilation index }>30^{*}\end{array}$ \\
\hline Renal & $\begin{array}{l}\text { Requirement for renal replacement therapy } \\
\text { such as peritoneal dialysis or hemofil- } \\
\text { tration and presence of one or more of } \\
\text { the following: } \\
\text { Urine output } \\
<0.5 \mathrm{ml} / \mathrm{kg} \text { per hour for } 4 \text { consecutive } \\
\text { hours or } \\
<300 \mathrm{ml} / \mathrm{m}^{2} \text { in } 24 \text { hours } \\
\text { Serum } \mathrm{creatinine} \\
>0.15 \mathrm{mmol} / \mathrm{L} \text { (age } 1 \text { to } 30 \text { days) } \\
>0.04 \mathrm{mmol} / \mathrm{L} \text { (age } 1 \text { to } 12 \text { months) } \\
>0.05 \mathrm{mmol} / \mathrm{L} \text { (age } 1 \text { to } 4 \text { years) } \\
>0.06 \mathrm{mmol} / \mathrm{L} \text { (age } 5 \text { to } 10 \text { years) } \\
>0.1 \mathrm{mmol} / \mathrm{L} \text { (age }>10 \text { years) }\end{array}$ \\
\hline
\end{tabular}

\section{Appendix Table I. Cont'd}

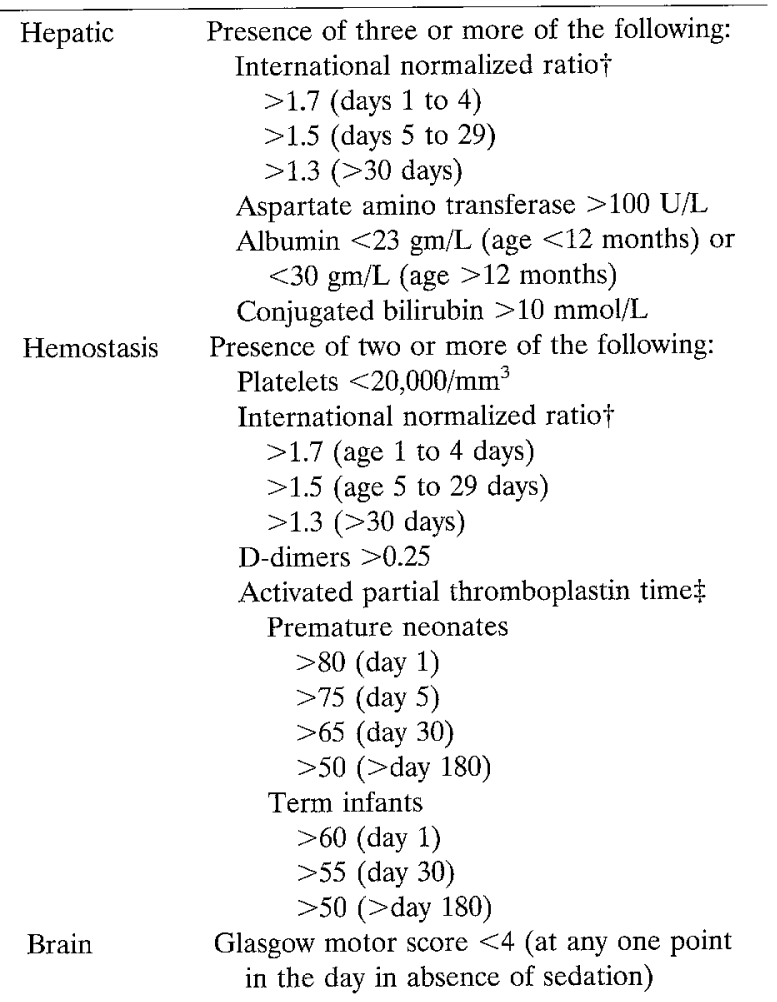

*Ventilation index $=[$ (Peak inspiratory pressure - Positive end-expiratory pressure) $\times$ Respiratory rate $\left.\times \mathrm{PaCO}_{2}\right] / 1000$.

$\dagger$ In the absence of warfarin anticoagulation.

$\ddagger$ In the absence of heparin anticoagulation. 